\title{
LISÄTIETOJA TORAJYVÄN VILJELYKOKEISTA VIIKIN KOETILALLA
}

\author{
AnNa-Lisa RUOKola \\ Yliopiston kasvipatologian laitos, Helsinki
}

Saapunut 13. 4. 1962

Torajyväsienen, Claviceps purpurea (FR.) TUL:n viljelykokeet Helsingin yliopiston opetus- ja koetilalla Viikissä aloitettiin v. 1952. Vuosina 1952-1959 suoritetuista kokeista on tulokset aikaisemmin julkaistu $(9,10,11,12)$. Ne käsittelevät paitsi sienen viljelyä, myös sen leviämistä rukiin talousviljelyksiin sekä koteloitiöiden välityksellä tapahtuvaa tartuntaa.

Viljelykokeita on edelleen jatkettu. Näissä tutkimuksissa pyrittiin mm. selvittämään typpi-, boori- ja kuparilannoitusten vaikutusta rukiin tähkissä kehittyvään torajyväsatoon. Samalla tutkittiin tähkien saastuttamiseen käytettyjen kuromasuspensioiden erilaisten konsentraatioiden vaikutusta satotuloksiin. Lisäksi vertailtiin rukiin tähkien keinotekoisesti suoritetun kuromasaastutuksen sekä toisaalta mesikasteen erittymiseen liittyvän ns. sekundäärisaastunnan vaikutuksia toisiinsa. Torajyväsienen leviämiseen kiinnitettiin niinikään huomiota.

\section{Kokeiden järjestely}

Vuosina 1960 ja 1961 oli torajyvän kasvuajan (noin kesä-heinäkuu) keskimääräinen lämpötila $17 \cdot 1^{\circ} \mathrm{C}$; v. 1959 se oli astetta korkeampi. Tämä kesän aika oli v. 1960 sateisin; vähäsateisin se oli v. 1959. Ilman suhteellisen kosteuden päivittäiset vaihtelut olivat suuret kaikkina koevuosina. Tavallisin tuulen suunta oli etelä-länsi.

Saastutuskokeisiin käytetyistä ulkomaisista torajyväkannoista yksi (kanta A) oli saatu Lääketehdas Leiraksesta; sen tarkkaa alkuperää ei ilmoitettu. Muut kannat, saksalainen $\mathrm{D}_{1}$ ja portugalilaiset $\mathrm{P}_{2}$ ja $\mathrm{P}_{3}$, olivat professori MoTHEsin Saksasta lähettämät. Kotimainen kanta, F, eristettiin Viikissä v. 1950. Saastutuksiin käytettiin Ensi-ruista.

Kuromien viljely tapahtui KIRCHноFin (7, vrt. 9) ohjeen mukaisesti valmistetuilla agari- ja nestemäisillä kasvualustoilla. Torajyvän kappaleet siirrostettiin aluksi agarivinopinnoille ja kuromien muodostumisen alettua niistä edelleen ravin- 
toliuospulloihin. Rukiin saastuttamiseen käytettiin pääasiallisesti nesteviljelmiä. Ennen tähkien käsittelyä viljelmien rihmasto murskattiin puristamalla se tiheän seulan läpi ja laimennettiin $5 \%$ :lla ruokosokeriliuoksella. Rihmasto oli tällöin keskimäärin kuukauden ikäistä. Saastutusnesteen sisältämien kuromien luku, tavallisesti noin 2.5 miljoonaa kuromaa millilitraa kohti, määritettiin Bürkerin laskukammiolla.

Saastutus suoritettiin samaa menetelmää käyttäen kuin aikaisemmin $(9,12)$. Ruis saastutettiin 8-12 päivää ennen kuin se alkoi kukkia, eli silloin kun $0-90 \%$ tähkistä oli vapautunut lehtitupesta.

Sato korjattiin noin viikkoa ennen rukiin tuleentumista. Torajyvät laskettiin kultakin koeruudulta yleensä $1 \mathrm{~m}^{2}: \mathrm{n}$ alalta. Tutkittavien koealojen sadot leikattiin sirpillä, koottiin lyhteiksi ja vietiin latoon, jossa torajyvien poiminta tapahtui. Näin käsitellyt lyhteet puitiin ja sadot lajiteltiin. Torajyvien lopullinen eroittaminen tapahtui trikloretyleenin ja petroolieetterin seoksessa, jonka ominaispaino oli 1.15. Tällöin rukiin jyvät painuivat astian pohjaan ja torajyvät jäivät nesteen pinnalle.

Tulosten luotettavuutta tarkasteltiin tilastomatemaattisesti BonNIER ja TEDINin (2) sekä Mudran (8) mukaisesti suoritetuilla varianssianalyyseillä.

\section{Typpilannoituskoe}

Vuosina 1959 - 1961 suoritettiin kokeita, joissa Ensi-ruis lannoitettiin oulunsalpietarilla ja saastutettiin $\mathrm{D}_{1}$-torajyväkannalla. Lannoite levitettiin oraille $\mathrm{v}$. 1959: 13. 5., v. 1960: 28. 4. ja v. 1961: 4. 5. Käytetyt lannoitemäärät olivat: 0, 100, $200,400 \mathrm{ja} 600 \mathrm{~kg} / \mathrm{ha}$. Koevuotta edeltäneenä syksynä koeruudut olivat saaneet perus-

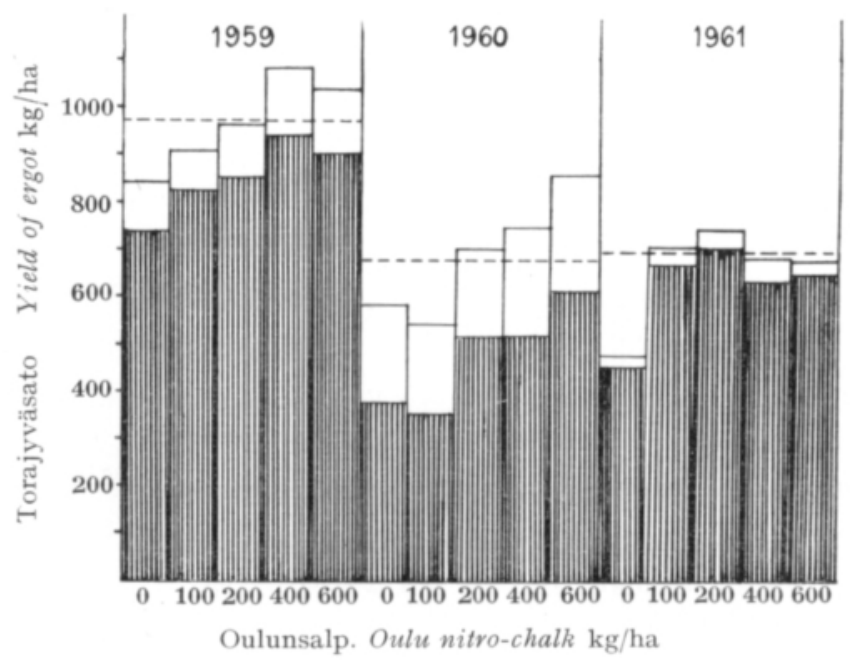

Kuva 1. Oulunsalpietarilannoituksen vaikutus Ensi-rukiin torajyväsadon määrään vuosina $1959-1961$. Valkeat pylväät $=$ maahan varisseet torajyvät. Katkoviivoitus osoittaa pienimmän luotettavan eron lannoittamattoman rukiin satoon verrattuna.

Figure 1. The effect of nitrogen fertilization on the ergot yield of Ensi rye in the years 1959-1961. White columns $=$ ergot grains fallen to the ground. The dashed lines indicate the least significant difference in comparison to the yield of unfertilized rye. 
lannoituksena 20 tonnia karjanlantaa, $300 \mathrm{~kg}$ superfosfaattia ja $160 \mathrm{~kg} 50 \%$ kalisuolaa hehtaaria kohti. Rukiin kylvömäärä oli tässä kuten muissakin kenttäkokeissa $150 \mathrm{~kg} / \mathrm{ha}$. Kerranteita oli vuosina 1959 ja 1960 5, v. 19613 . Koeruutujen alkuperäinen koko oli $5 \mathrm{~m}^{2}$; torajyvät laskettiin $1 \mathrm{~m}^{2}$ :n aloilta.

Salpietarilannoitus lisäsi torajyväsadon määrää kaikkina koevuosiṇa (kuva 1). Tähkäluku ruisyksilöä kohti kasvoi lannoituksen vaikutuksesta keskimäärin 3.27:stä 3.96:een. Torajyvien koossa ilmeni typpilannoituksen aiheuttamaa selvää suurentumista vain v. 1960 .

\section{Hivenainelannoituksen vaikutus torajyväsatoon}

Viime aikoina on meillä alettu kiinnittää huomiota siihen, että alueilla, joiden maaperässä on ollut vain niukasti booria ja kuparia, hivenainelannoitus on vaikuttanut edullisesti rukiin jyväsadon määrään ja samalla aiheuttanut sadon torajyväpitoisuuden jäämisen verraten pieneksi (15).

Kasvipatologian laitoksessa asiaa pyrittiin selvittämään kokeella, jossa rukiille annettiin peruslannoituksen lisäksi boori- ja kuparilannoitus. Hivenaineet annettiin pintalannoituksena 2. 5. 1961. Koejäsenet olivat: a) ilman hivenaineita, b) booraksia $10 \mathrm{~kg} / \mathrm{ha}, \mathrm{c}$ ) kuparisulfaattia $50 \mathrm{~kg} / \mathrm{ha}$ ja d) booraksia $10 \mathrm{~kg} / \mathrm{ha}+\mathrm{kupari}-$ sulfaattia $50 \mathrm{~kg} / \mathrm{ha}$. Ruis saastutettiin A-torajyväkannalla. Kerranteita oli 4 . Koeruutujen koko oli $2 \mathrm{~m}^{2}$; sato korjattiin koko koeruudulta.

Taulukko 1. Ensi-rukiin hivenainelannoituskokeen torajyväsadot v. $1961\left(4 \times 2 \mathrm{~m}^{2}\right)$. Maalaji hiekkasavi. Torajyväkanta A.

Table 1. The yields of ergot in trace element fertilization trial of Ensi rye, 1961. Soil type sandy clay; four plots of $2 \mathrm{~m}^{2}$; ergot strain $A$.

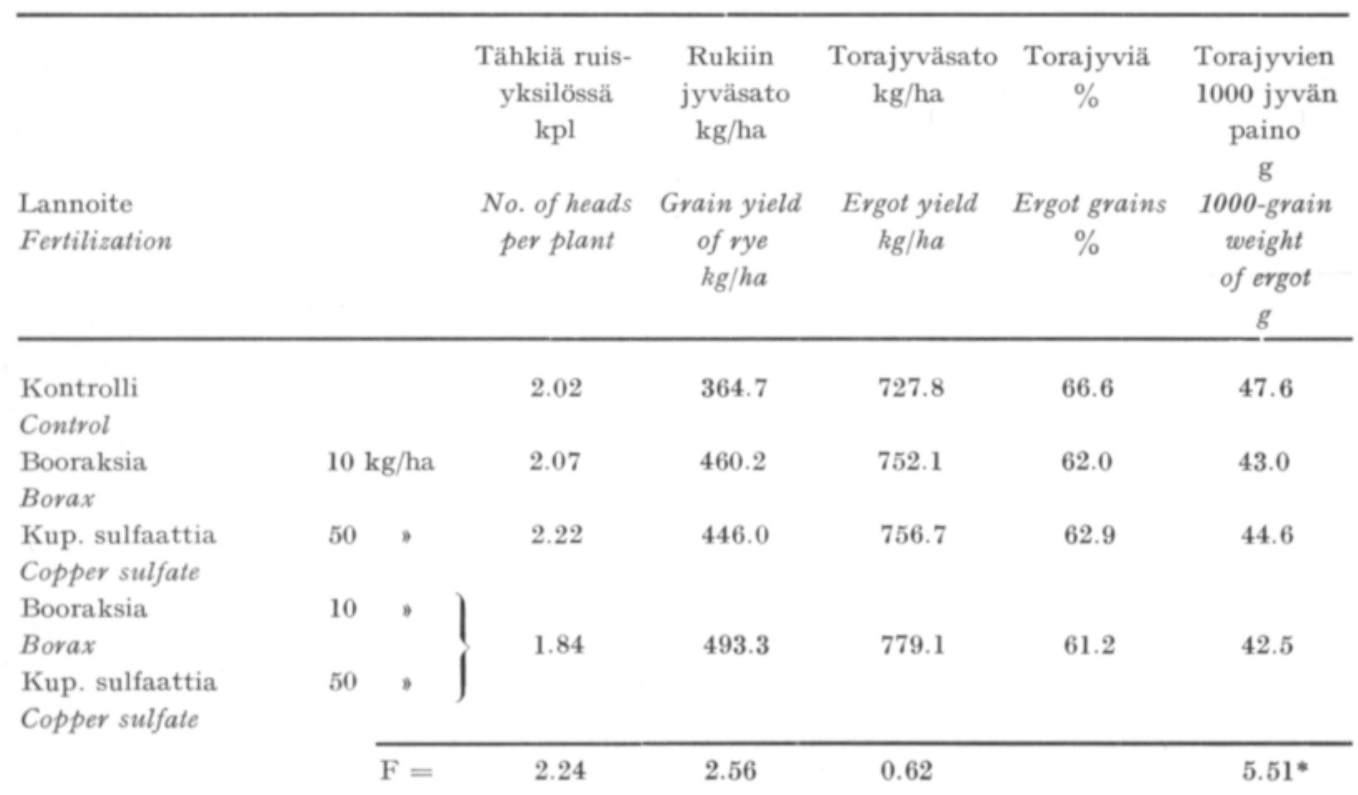


Huolimatta siitä, että Ensi-rukiin kasvusto keväällä, 4. 5. suoritettujen havaintojen mukaan oli jonkin verran harventunutta (tiheys $6-10 ; 10=$ täystiheä), muodostuivat torajyväsadot varsin suuriksi (taulukko 1). Torajyviä oli enemmän booria ja kuparia saaneissa kuin lannoittamattomissa kasvustoissa, joskaan nämä erot eivät olleet tilastollisesti luotettavia. Kun kuitenkin hivenainelannoitus vaikutti vielä enemmän rukiin jyväsadon kuin torajyväsadon määrään, aiheutti lannoitus torajyväisyysprosentin vähäistä pienentymistä. Torajyväsienellä saastutetuissa kasvustoissa moni tähkä muodosti pääasiassa vain torajyviä. Näin ollen rukiin jyväsato jäi hyvin pieneksi.

\section{Lämpötilan ja kosteuden vaikutus kuromien kasvuun}

Sphacelia-kuromien muodostuminen on ollut erilaista sen mukaisesti, minä ajankohtana ne on viljelty. Eräässä koesarjassa kuromien viljely aloitettiin KIRCHHOFFin ravintoagarialustalla, Petrin maljoissa 29. 1., 4. 3., 30. 3. ja 29. 4. Termostaatissa, jossa viljelmät säilytettiin, oli koko kokeen ajan sama lämpötila, $22^{\circ} \mathrm{C}$. Kunakin ajankohtana sieni siirrostettiin samojen sklerotioiden (kaksi) kappaleista, joten kerranteita oli 2. Kuromien laskeminen suoritettiin noin yhden ja puolentoista kuu-

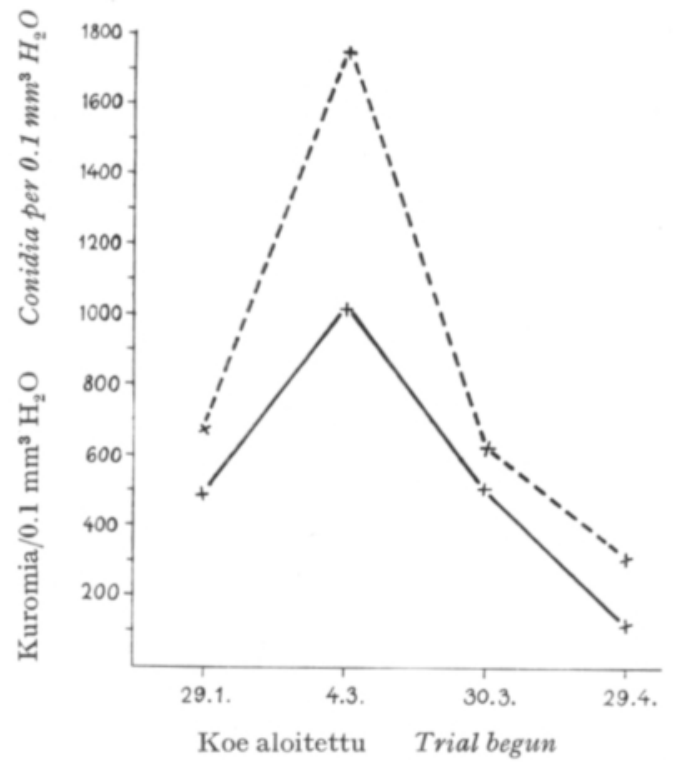

Kuva 2. Sphacelia-kuromien muodostumisrunsaus eri ajankohtina suoritetuissa Petrinmaljakokeissa, joissa kasvualustana oli KrRchноғFin agari. Torajyväkanta $D_{1}$.

Figure 2. The amount of $S p h$ a c e li a conidia of the ergot strain $D_{1}$ formed at various times in Petri dish trials. Culture medium $=$ KIRCнноFF's agar.

$=\mathrm{n} .1$ kuukauden ikäiset viljelmät cultures about 1 month old

$------=$ n. $1 \frac{1}{2}$ kuukauden ikäiset viljelmät cultures about 1 1/2 month old 
kauden ikäisistä viljelmistä. Laskemista varten jokaisesta agarialustaviljelmästä otettiin korkkiporalla 4 näytettä, kaksi viljelmän reunasta, kaksi yhden cm:n päästä keskipisteestä. Kunkin näytteen kuromat erikseen sekoitettiin 20-60 millilitraan tislattua vettä, josta ne laskettiin. Kuvan 2 käyrien esittämät kuromaluvut ovat näytteiden keskiarvolukuja. Kuromia muodostui eniten viljelmissä, jotka oli pantu kasvamaan 4. 3.; sitä ennen (29. 1.) ja sen jälkeen, varsinkin 29. 4. aloitetuissa kokeissa, kuromia muodostui selvästi vähemmän. Kuromia oli säännöllisesti enemmän puolentoista kuukauden kuin yhden kuukauden ikäisissä viljelmissä.

Eräissä toisissa kokeissa koetettiin selvittää syytä siihen, miksi kuromanmuodostuksen runsaus eri kokeissa vaihteli. Torajyväsieni kasvatettiin sklerotion kappaleesta. Näin saadun Petrinmaljaviljelmän reunasta otettiin korkkiporalla sienen rihmastoa ja kuroma-astetta ja siirrostettiin 100 millilitran vetoiseen Erlenmeyerpulloon, jossa oli $25 \mathrm{ml} \mathrm{KIRCHHOFFin} \mathrm{ravintoliuosta.} \mathrm{Pulloa} \mathrm{ravistettiin} \mathrm{sekä} \mathrm{heti}$ siirrostuksen jälkeen että kaksi vuorokautta myöhemmin. Pullot pidettiin eri lämpö-

Taulukko 2. Sphacelia-kuromien ja -rihmaston muodostuminen Кıснноғғin ravintoliuoksessa erilaisissa olosuhteissa 8, 3.-7, 4. 1961. Torajyväkanta A, kerranteita 3 .

Table 2. The formation of conidia and mycelia of $S p$ h a cel $i$ a on KIRchноғF's culture medium under various conditions, March 8-April 7, 1961. Ergot strain A; 3 replicates.

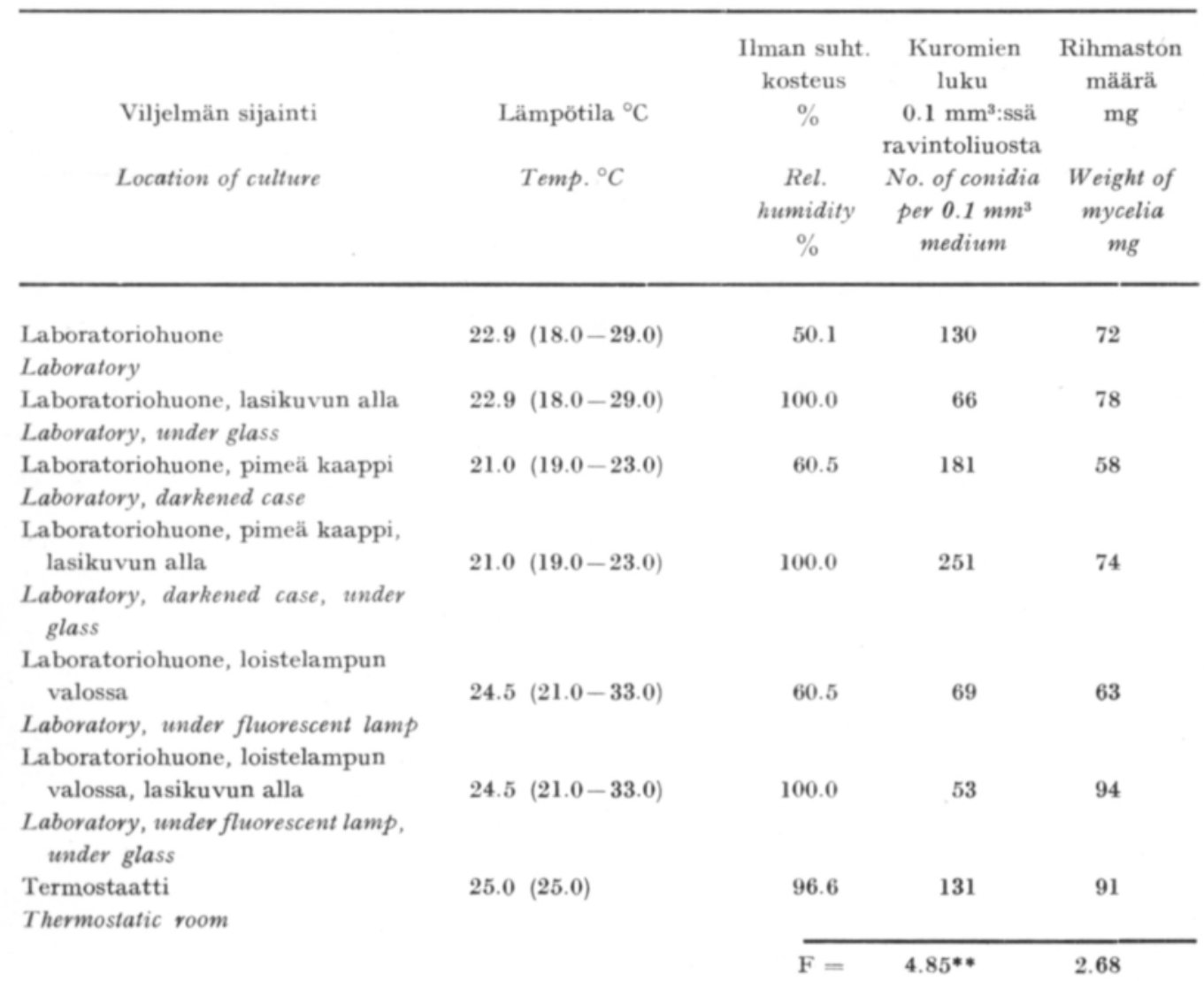


tiloissa; koska osa sienestä kasvoi nesteen pinnalla, määritettiin ilman suhteellinen kosteus. Kuromat laskettiin kuukauden ikäisistä viljelmistä. Lisäksi määritettiin kussakin viljelmässä muodostuneen rihmaston määrä seuraavasti (vrt. 16): Imupumpulla imettiin ravintoliuos jokaisesta pullosta ja jäljelle jäänyt sienimassa kiehautettiin tislatussa vedessä. Vesi kaadettiin tarkoin pois, ja huuhtominen toistettiin kaksi kertaa, ensiksi kuumalla ja sitten kylmällä tislatulla vedellä. Näytteet kuivattiin kuivauskaapissa $65^{\circ} \mathrm{C}$ :n lämpötilassa 2 vuorokauden ajan ja rihmaston määrä punnittiin (taulukko 2).

Kuromia muodostui eniten, kun lämpötila oli keskimäärin $21^{\circ} \mathrm{C}$; KIRCHHOFF (7) pitää sopivimpana lämpötilana $17-20^{\circ} \mathrm{C}, \operatorname{HECKE}(4) 25^{\circ} \mathrm{C}$. Myös viljelmiä ympäröivän ilman suuri suhteellinen kosteus näytti ainakin eräässä tapauksessa edistävän kuromien kasvua. Valon merkitys sen sijaan jäi epäselväksi, koska valoisuuden lisääntyessä myös lämpötila huomattavasti kohosi.

Kaksi muuta koetta, joissa kuromat kasvatettiin KIRCHHOFFin ravintoagarilla Petrin maljoissa, suoritettiin keskenään lähes samoissa kosteus- ja lämpötilaolosuhteissa (taulukko 3); toinen koe aloitettiin noin viikkoa myöhemmin kuin ensimmäinen. Kummassakin kokeessa kuromia kasvatettiin sekä valossa että pimeässä. Kuromia muodostui merkitsevästi enemmän 23. 5. kuin 15. 5. aloitetun kokeen viljelmissä. Paitsi ilman lämpötilaa ja suhteellista kosteutta lienee siis muitakin tekijöitä, jotka vaikuttavat kuromien muodostumisrunsauteen. KIRCHHOFF (7) kasvatti infektiomateriaalinsa rukiin torajyväsaastutuksia varten pimeässä.

Taulukko 3. Sphacelia-kuromien muodostuminen КІRснноғFin ravintoagarilla erilaisissa olosuhteissa v. 1961. Torajyväkanta A.

Table 3. The formation of $S p h$ a cel i a conidia of the ergot strain $A$ on KrRchHofr's culture medium under various conditions in 1961.

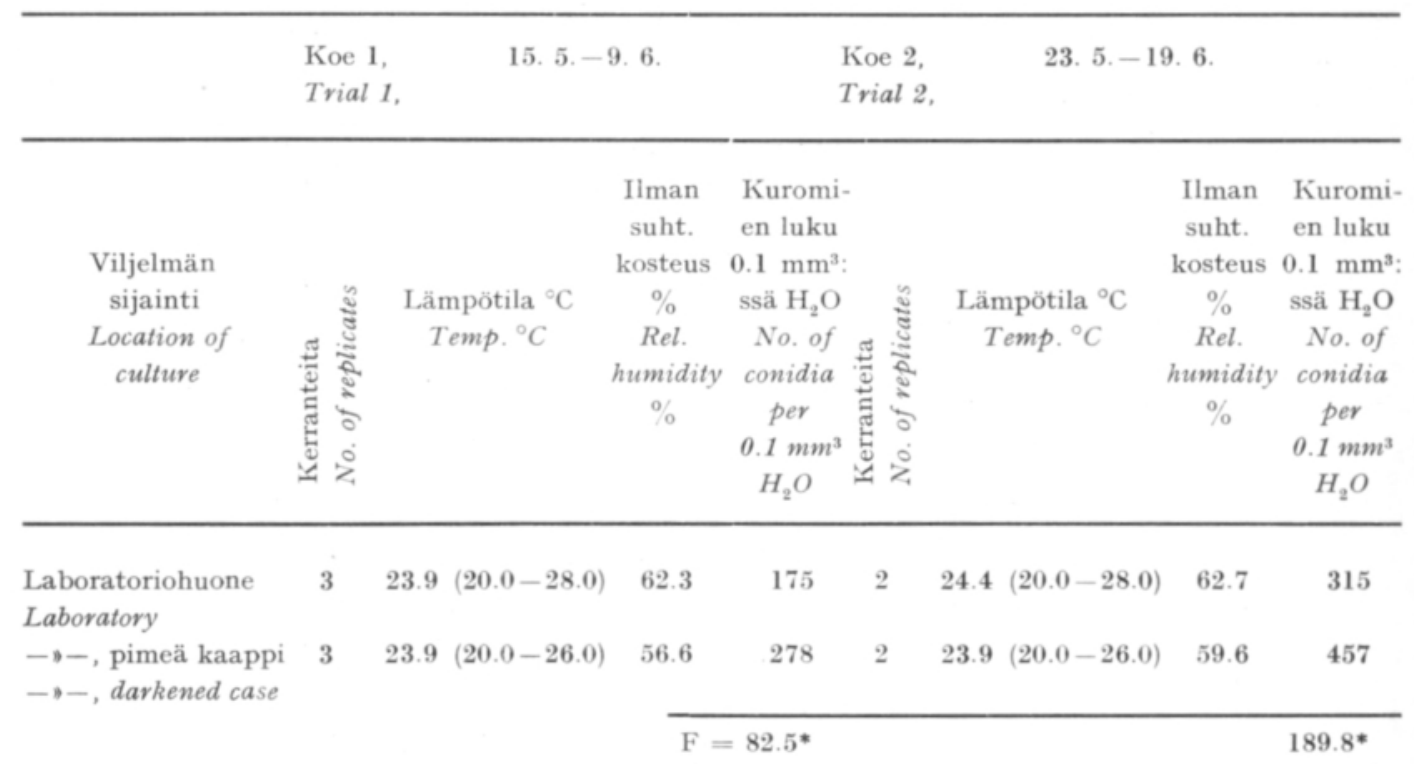




\section{Saastutukseen käytetyn kuromamäärän vaikutus rukiin torajyväsatoon}

Onnistuneen torajyvän viljelyn eräs tärkeä edellytys on, että saastutusneste, jolla rukiin tähkät käsitellään, sisältää riittävästi kuromia. Alan tutkijoiden parhaina pitämät kuromaluvut ovat toisistaan melkoisesti poikkeavia $(1,14,17)$. Leiraksen (5) torajyväviljelyksillä on saatu hyviä tuloksia saastutussuspensiolla, joka sisälsi noin 200000 kuromaa nestemillilitraa kohti. Viikin koetilalla vuosina 1960-1961 suoritetuissa asian selvittämiseksi järjestetyissä kokeissa käytettiin Ensi-rukiin saastuttamiseen 5\% ruokosokeriliuoksen millilitraa kohti 25000 , 250000 ja 2500000 kuromaa. Koeruutujen tutkitut alat olivat $1 \mathrm{~m}^{2}$; kerranteita oli 4. V. 1960 torajyvien muodostuminen kaikissa koeruuduissa oli keskenään jokseenkin yhtä nopeata; v. 1961 se oli $2-5$ vuorokautta hitaampaa vähiten kuromia saaneissa kuin muissa kasvustoissa. Mesikastetta niissä muodostui erittäin niukasti, ja tuleentunut torajyväsato jäi verraten pieneksi. Torajyväsato oli sitä suurempi, mitä enemmän saastutussuspensio sisälsi kuromia (taulukko 4).

Taulukko 4. Saastutukseen käytetyn suspension kuromaluvun vaikutus Ensi-rukiin torajyväsadon määrään keskimäärin vuosina $1960-1961$. $\left(4 \times 1 \mathrm{~m}^{2}\right)$. Torajyväkanta $\mathrm{D}_{1}$.

Table 4. The effect of number of conidia in the inoculation suspension on the ergot yield of Ensi rye. Averages from the years $1960-1961$. Four plots of $1 \mathrm{~m}^{2}$. Ergot strain $D_{1}$.

\begin{tabular}{|c|c|c|c|c|}
\hline \multirow[b]{2}{*}{ Kuromia/ml } & \multicolumn{3}{|c|}{$\begin{array}{l}\text { Torajyviä } \mathrm{kg} / \mathrm{ha} \\
\text { Ergot grains }\end{array}$} & \multirow[b]{2}{*}{ Sl. } \\
\hline & $\begin{array}{c}\text { Poimittuja }+ \text { puidussa } \\
\text { sadossa }\end{array}$ & Varisseita & Yhteensä & \\
\hline $\begin{array}{l}\text { No. of conidia } \\
\text { per } m l\end{array}$ & In the heads & $\begin{array}{l}\text { Fallen to } \\
\text { the ground }\end{array}$ & Total & Rel. \\
\hline 25000 & 157.9 & 60.1 & 218.0 & 100 \\
\hline 250000 & 194.3 & 61.9 & 256.2 & 118 \\
\hline 2500000 & 250.1 & 66.4 & 316.5 & 145 \\
\hline
\end{tabular}

Luotettava satoero $\mathrm{kg} / \mathrm{ha}$ Significant yield difference $\mathrm{kg} / \mathrm{ha} \quad(\mathrm{P}=0.05) \quad 50.9^{*}$

\begin{tabular}{|c|c|c|c|c|c|c|c|c|}
\hline b & - & , & - & , & , & , & $(\mathrm{P}=0.01)$ & $70.4^{* *}$ \\
\hline , & , & , & , & , & , & , & $(\mathrm{P}=0.001)$ & $97.3^{* * * *}$ \\
\hline
\end{tabular}

Tähkien kuromasuspensiokäsittelyn aiheuttaman ja mesikasteen erittymiseen liittyvän saastunnan vaikutus rukiin torajyväsatoon

Edellä selostetuissa kokeissa rukiin torajyväsadot perustuivat välittömään tähkien kuromasuspensiokäsittelystä johtuneeseen ja toisaalta mesikasteen erittymiseen liittyneeseen sekundääriseen saastuntaan. Kysymystä siitä, kumpi näistä saastuntamuodoista on pääasiallisempi torajyväsatojen aiheuttaja, pyrittiin selvittämään vuosina 1960-1961 suoritetuilla kokeilla. 
Koeruutuja oli 8; niissä oli 7 kylvöriviä. Joka toisen koeruudun kasvusto saastutettiin $\mathrm{D}_{1}$-torajyväkannalla kokonaan, muissa koeruuduissa saastutettiin vain keskimmäinen rivi. Koeruutujen väli oli $50 \mathrm{~cm}$, riviväli oli $10 \mathrm{~cm}$ v. 1960 ja $20 \mathrm{~cm}$ v. 1961. Tutkitun riviosan pituus oli $1 \mathrm{~m}$.

V. 1961 saastutetun rukiin torajyväsadot (tähkistä poimitut + maahan varisseet + puidusta viljasta eroitellut torajyvät) olivat käsittelemättömän rukiin torajyväsatoja selvästi suurempia (kuva 3). Sen sijaan v. 1960 torajyväsieni levisi sangen voimakkaasti saastuttamattomiin kasveihin. Tähän lienee ainakin osaksi vaikuttanut että saastutusaikaa seurannut kausi oli erittäin kostea ja että hyönteisiä oli hyvin runsaasti. Sitä paitsi kylvörivien väli oli v. 1960 pienempi kuin v. 1961.

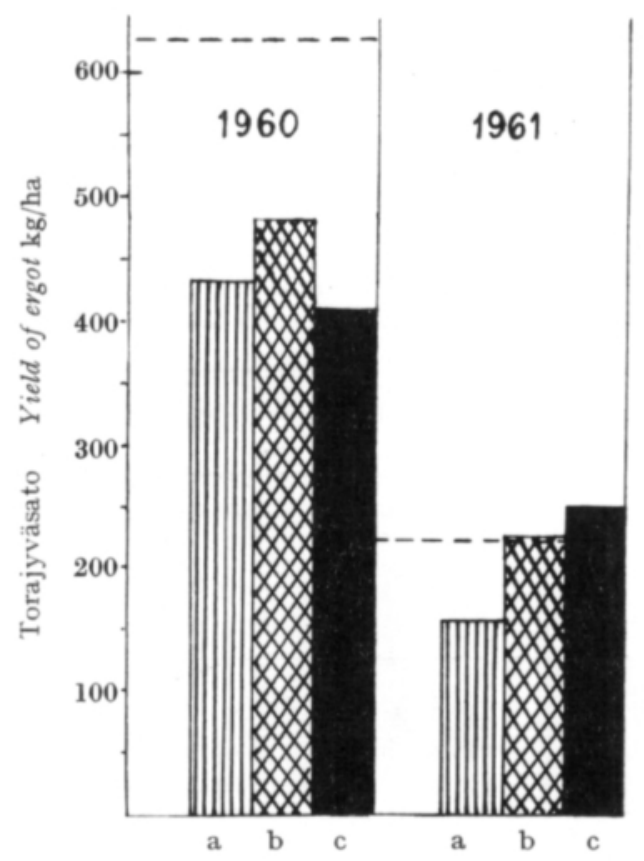

Kuva 3. Tähkien kuromasuspensiokäsittelyn ja sekundäärisaastunnan vaikutus Ensi-rukiin torajyväsadon määräăn vuosina 1960 - 1961. Katkoviivoitus osoittaa pienimmän luotettavan eron saastuttamattoman rukiin satoon verrattuna.

Figure 3. The effect of conidial inoculation and secondary infection on the yield of ergot in Ensi rye in the years 1960-1961. The dashed lines indicate the least significant difference in comparison to the yield of uninoculated rye.
$\mathrm{a}=$ Koeruutujen saastuttamattomat reunarivit uninoculated border rows
$\mathrm{b}=$ Koeruutujen saastutetut keskirivit inoculated center rows
$\mathrm{c}=$ Koeruutujen koko kasvusto saastutettu entive plot inoculated 


\section{Torajyväsienen leviäminen saastutetuista kasvustoista rukiin talousviljelyksiin}

Suomalaisen torajyvän alkaloidipitoisuus on erittäin pieni (6). Vastaavasti se ei myöskään ole yhtä myrkyllinen kuin ulkomaiset, runsasalkaloidiset torajyväkannat. Ulkomaisten torajyväkantojen leviämiseen saastutetun rukiin lähiympäristöön on yliopiston kasvipatologian laitoksen tutkimuksissa kiinnitetty jatkuvasti huomiota. Syksyllä 1961 selvitettiin koetilan ruisviljelyksiltä otettujen torajyvänäytteiden alkaloidipitoisuuksia. Näytteet kerättiin paikoista, joiden etäisyys saastutetuista aloista vaihteli 0.6 :sta 850 metriin. Alkaloidimäärityksissä noudatettiin pääasiallisesti Sмrтнin (13) U.S.A.:ssa käyttämää menetelmää, joka perustuu alkaloidien yhteismäärän kolorimetriseen selvittämiseen. Alkaloidimäärät ilmaistiin ergotamiiniprosentteina torajyvän kuiva-aineesta. Tällöin saatiin seuraavat tulokset:

Etäisyys saastutetusta alasta, $\mathrm{m}$
Distance from the inoculated plot, $m$

Ulkomaisella torajyväkannalla saastutetut kasvit

Rye plants inoculated with foreign ergot strains

$0.6-1$

$6-16$

$500-850$

Suomalaisella torajyväkannalla saastutetut kasvit

Rye plants inoculated with Finnish ergot strains

$\begin{gathered}\text { Torajyvissä alkaloideja } \\ \text { (ergotaminina) }\end{gathered}$
$\begin{gathered}\text { Total alkaloid content of ergots } \\ \text { (as ergotamine) } \\ \%\end{gathered}$
0.295
0.270
0.268
0.168
0.004

Toistensa välittömässä läheisyydessä kasvaneiden saastuttamattomien ja ulkomaisella torajyväkannalla saastutettujen ruiskasvustojen torajyvien alkaloidipitoisuus oli keskenään lähes yhtä suuri. Saastutetuista kasvustoista kauempana muodostuneiden torajyvien alkaloidipitoisuus oli selvästi pienempi, mutta kuitenkin niin suuri, että voidaan päätellä torajyväsientä kulkeutuneen ainakin $850 \mathrm{~m}: \mathrm{n}$ etäisyydelle saastutetusta rukiista. Torajyväsienen siirtäjinä lienee hyönteisillä ollut ratkaiseva merkitys (vrt. $1,3,10$ ).

\section{$P \ddot{a} \ddot{t}$ el $m \ddot{a} t$}

Pintalannoituksena annettu oulunsalpietari lisäsi rukiin torajyväsatoa. Torajyvän kokoa salpietarilannoitus suurensi vain vähän.

Boori- ja kuparilannoitus lisäsivät enemmän rukiin jyvä- kuin torajyväsatoja. Täten lannoitus vähän pienensi sadon torajyväpitoisuutta.

Saastutussuspension kuromamäärän kohottaminen 25000 kuromasta millilitraa kohti 10- ja 100-kertaiseksi aiheutti torajyväsadon huomattavan (18-45\%) suurentumisen. 
Mesikastesaastunnan vaikutus torajyväsatoon oli vuosina 1960 - 1961 huomattavan suuri. V. 1960 olivat kuromasuspensiolla saastutettujen ja näistä $10-50$ $\mathrm{cm}:$ n etäisyyksillä olleiden saastuttamattomien ruiskasvustojen torajyväsatojen määrät keskenään lähes samat.

Runsasalkaloidista torajyväsientä todettiin kulkeutuneen ainakin $850 \mathrm{~m}: \mathrm{n}$ etäisyydelle saastutetuista kasvustoista.

\section{KIRJALLISUUTTA}

(1) BÉKÉsy, N. von 1938. Über parasitische Mutterkornkulturversuche. Zbl. Bakt. Parasitenkunde 99: $321-332$.

(2) Bonnier, G. \& Tedin, O. 1940. Biologisk variationsanalys. 1940. $325 \mathrm{~s}$. Stockholm.

(3) Неснт, W. 1953. Zur Frage der Ausbreitung von Mutterkorninfektionen. Bodenk. 7: 363-371.

(4) Hecke, L. 1922. Die Kultur des Mutterkorns. Schw. Apoth. Ztg. 60:45-51.

(5) Honkavanra, E. 1959. 10 vuotta kotimaista torajyvänviljelyä. Käytännőn lääkäri 1959, 4: 36-44.

(6) JÄrVinen, P. A. 1953. Uber die pharmakodynamischen und klinischen Wirkungen des finnischen Mutterkorns. 82 s. Helsinki.

(7) Kirchноғғ, H. 1929. Beiträge zur Biologie und Physiologie des Mutterkornpilzes. Cbl. Bakt. Parasitenkunde 77: $310-369$.

(8) Mudra, A. 1958. Statistische Methoden für landwirtschaftliche Versuche. $336 \mathrm{~s}$. Berlin-Hamburg.

(9) RuокоцА, A-L. 1956. Torajyvän viljelykokeista Viikin koetilalla ja eräillä kasvinviljelyskoeasemilla Suomessa. Referat: Úber Anbauversuche von Mutterkorn auf dem Versuchsgut Viik und an einigen Versuchsstationen für Pflanzenbau in Finnland. Maatal.tiet.aikak. 28: $203-222$.

(10) - - 1957. Torajyväsienen, Claviceps purpurea (Fr.) Tul.:n leviämisestä ja torjunnasta. Referat: Úber Ausbreitung und Bekämpfung des Mutterkornpilzes, Claviceps purpurea (Fr.) Tul. Ibid. 29: $82-91$.

(11) - - 1957. Torajyväsienen, Claviceps purpurea (Fr.) Tul.:n sklerotioiden itämisestä. Referat: Uber das Keimen von Sklerotien des Mutterkornpilzes, Claviceps purpurea (Fr.) Tul. Ibid. 29: $218-228$.

(12) - - 1960. Torajyvän tuotantomahdollisuuksista Suomessa. Summary: Possibilities of ergot production in Finland. Maatalous ja koetoiminta 14: 248-259.

(13) Sмгтн, R. G. 1947. Report on a collaborative study of the assay of ergot. J. Am. Pharm. Ass. 36: $321-331$.

(14) Stoll, A. 1943. Altes und Neues über Mutterkorn. Mitt. Naturf. Ges. Bern 1942. 1943: 45-80.

(15) TAINıO, A. 1961. Voidaanko hivenaineilla torjua torajyvää? Koetoiminta ja käytäntö 18: 38, 40.

(16) Vartiovatara, U. 1935. Maaperän sienten aineenvaihduntaa koskevia tutkimuksia. Summary: Studies on the metabolism of soil fungi. S. maatal.tiet.seur.julk. 32. Erip., $112 \mathrm{~s}$.

(17) Wiechert, E. 1952. Mutterkornanbau in Mecklenburg. Pharmazie 7: 859-862. 
S U M M A R Y :

ADDITIONAL RESULTS FROM ERGOT FIELD TRIALS AT VIIK EXPERIMENTAL FARM

AnNa-Lissa Ruokola

Department of Plant Pathology, University of Helsinki

In continuation trials carried out at Viik Experimental Farm in the years 1959-61 investigations were made on various factors influencing ergot yields in fields of rye. Among the results obtained, the following can be mentioned:

A surface dressing of nitrogen fertilizer increased the yield of ergot (Fig. 1). The size of the ergot grains was only slightly increased by the nitrogen treatment.

Boron and copper dressings increased the grain yield of rye more than the yield of ergot. Thus this treatment reduced the ergot content of the rye (Table 1).

When the concentration of conidia in the inoculation suspension $(25000$ per ml) was increased 10 or 100 times, the ergot yield was correspondingly increased $18 \%$ and $45 \%$, respectively (Table 4).

Secondary infection was found to have an appreciable effect on the yield of ergot in the years $1960-61$ (Fig. 3). In 1960 the amount of ergot was practically the same in rye plants inoculated with conidial suspension and in uninoculated plants situated $10-50 \mathrm{~cm}$ distant.

Certain foreign strains of ergot high in alkaloid content were found to be spread at least 850 meters from the initially infected stands (Tabulation on page 129). 